\title{
The Brazilian Mobile Telephoning Market and Its Indicators of Non-quality
}

\author{
Jamil Ramsi Farkat Diógenes, Kleber Cavalcante de Sousa, Benilton Medeiros Nunes, \\ Fernanda Cristina Barbosa Pereira Queiroz, Jamerson Viegas Queiroz, Hélio Roberto Hékis \\ UFRN, Natal/RN, Brasil
}

\begin{abstract}
This article aims to scale the Brazilian mobile phone market as the number of active lines, carriers participation in the market and teledensity, as well as presenting the main non-quality indicators and rankings of carriers in relation to complaints registered by users. The methodology used was "survey" with documentary research, enabled through access to the database of the Brazilian National Telecommunications Agency-ANATEL, and Sindec Report developed by the Brazilian National Secretary of the Consumer-SENACON. The results obtained showed a Brazil of had a teledensity of 132.78 lines every 100 inhabitants, with 261 million mobile lines active, these 19 million enabled in 2012. The leadership of the company "Vivo" with 29.08\% of marketshare and shows the lowest rate of complaints among the big four carriers (Vivo, TIM, Claro, and Oi Móvel) according to the data of Anatel. SENACON data already confirm the big four carriers among the 10 conglomerates more defendants in claims in Brazil. As the indicators of non-quality, the Act of Misappropriation was pointed to by users as the biggest problem in contracted services.
\end{abstract}

Keywords: quality, regulatory agency, Brazilian mobile telephony

\section{Introduction}

In the world there are 6.3 billion mobile phones in circulation, and in the global mobile-phone market, Brazil appears between the five biggest, behind countries like China, India, United States, and Indonesia. The growth observed in Brazil in 2012 as the number of cell phones, corresponds to 7.4\% from 2011 (ITU, 2012).

The market growth has not been accompanied by improvements in operating infrastructure, being notorious dissatisfaction in society regarding the contracted services of mobile telephony in the country. According to Brazilian National Secretary of the Consumer-SENACON (2012), cellular telephony was the leader of claims in all Brazilian consumer protection institutes, where in the year 2012 registered 172,119 complaints, representing $9.17 \%$ of the total computed, with the major mobile phones carriers among the "top 10

Jamil Ramsi Farkat Diógenes, M.Sc. Student in Production Engineering, Production Engineering Department, UFRN.

Kleber Cavalcante de Sousa M.Sc. Student in Production Engineering, Production Engineering Department, UFRN.

Benilton Medeiros Nunes, M.Sc. Student in Production Engineering, Production Engineering Department, UFRN.

Fernanda Cristina Barbosa Pereira Queiroz, Ph.D. in Production Engineering, Professor of Production Engineering Department, UFRN.

Jamerson Viegas Queiroz, Ph.D. in Production Engineering, Professor of Production Engineering Department, UFRN.

Hélio Roberto Hékis, Ph.D. in Production Engineering, Professor of Production Engineering Department, UFRN.

Correspondence concerning this article should be addressed to Jamil Ramsi Farkat Diógenes, Production Engineering Department, UFRN, Brazil. E-mail: farkatt@gmail.com. 
rank" business champions in complaints, with the operator Oi Móvel in first place, followed by Claro in second, Vivo in fifth, and TIM in seventh. These carriers are the four largest in market share (ANATEL, 2012).

Aware of this reality, the Brazilian National Telecommunications Agency-ANATEL, exercising its role as a regulatory body, has been operators charging the provision of quality services. Not having effective response requests in the year 2012 the ANATEL imposed in June a punishment at TIM, Oi Móvel, and Claro, suspending their sales in several Brazilian Federal States during 12 days (TELECO, 2012).

In addition to the sales suspension, other means of punishment used by ANATEL is through the application of fines in cash. Until 2012, the Agency recorded 4,974 penalties applied, these only 2,400 were paid by carriers, totaling an amount of USD 6.48 million dollars and leaving the Agency receive about USD 93.85 million dollars. The non-fulfillment of this obligations lead carriers restricting the issuance of clearance certificates of debt which creates impediment in the acquisition of government concessions to construction of new transmission stations, affecting plans for improvement (UOL, 2013).

In this context, using the ANATEL database as a means to make a case study of mobile operators in Brazil, this article objective is describe the Brazilian mobile phone market, in questions about your size, number of active lines, carriers' participation in the market and teledensity, as well as presenting all of non-quality indicators and rankings of carriers in relation to complaints registered by ANATEL and SENACON. The results displayed will serve to alert consumers about the deficiencies in the services contracted, causing seek alternatives on another carrier, or when there is no other option, stay aware of the frequent problems.

For both the organization of the present study begins with this introduction, followed by section two "Quality: Concept and Evolution", section three "The Quality Management Promoting Competitiveness", section four "ANATEL", and section five "Brazilian Mobile Phone Operators". The sections two, three, four, and five contain relevant concepts to this research. In continuity, section six presents "The Research Method", which is the methodological procedure used to develop this research. Section seven shows the "Results". Lastly, section eight shows the "Conclusions".

\section{Quality: Concept and Evolution}

Since 1950, the use of the concepts of quality within the production processes has enabled the evolution of organizations. Given that various authors have produced research on the topic, allowing the understanding of what really proves the quality (Diogenes, Sousa, Queiroz, Queiroz, \& Hékis, 2013).

It was noticed during the time that the focus of quality has been expanding, seeking to reach not only the conformity of the product, but also the personal satisfaction of the clients, as shown in Table 1, entered the concepts of quality drawn up by Crosby (1990), Juran (1990), Feigenbaum (1994), Ishikawa (1993), and Deming (1993).

Table 1

Quality Concepts

\begin{tabular}{|l|l|}
\hline Author & Quality concept \\
\hline Crosby & Quality is defined in terms of compliance with the specifications. \\
\hline Juran & Quality is the absence of deficiencies, that is, the fewer defects, the better the quality. \\
\hline Feigenbaum & Quality means the best for certain conditions of the client. These conditions are: the real use and the selling price. \\
\hline Ishikawa & Quality means continuous search of consumer needs, through: quality of product, service, business, people, and time. \\
\hline Deming & Quality is compliance with current and future needs of the consumer. \\
\hline
\end{tabular}


Ratifying the quality concepts described by Ishikawa (1993) and Deming (1993), ABNT (2008) defined quality as a set of properties and characteristics of a product, process or service, with the ability to satisfy the needs expressed or implied. It is recognized that currently the quality of products/services is a preponderant factor in achieving customer satisfaction (Srivastav, 2010).

Organizations grow from achievements and maintaining customers. For both the preparation of products/services must be designed around the current concepts of quality, customer satisfaction (Diogenes et al., 2013).

In that context, the quest for quality and excellence in management has been considered as priority strategic objective in many global enterprises, ensuring quality as a competitive priority (Fuentes-Fuentes, Llorens-Montes, Molina-Fernandes, \& Albacete-Saez, 2011).

\section{The Quality Management Promoting Competitiveness}

Powell (1995) believed that there is a positive relationship between quality management, competitiveness and management excellence.

According to Kaynak (2003) and S. Lagrosen and Y. Lagrosen (2003), quality management helps to improve the financial performance and operational practices, facilitating the company to create competitive advantage. Understanding this scenario global companies like Xerox, Ford, Motorola, and Federal Express, has been adopting two decades quality management processes (Powell, 1995; Rahman, 2004).

Commercial and financial globalization has reduced borders made possible by advances in technology in the service of creating new sales channels and logistics. With this increased scope of organizations acting doing extremely fierce competition is born. In this way, there is a constant and growing concern in the pursuit of customer satisfaction as a way to retain it (Levitt, 1990)

Quality management assists in the implementation of loyalty programs, because the act of customer loyalty to be influenced by the existence of products/services with quality, providing customer satisfaction. For Churchill and Peter (2003) loyalty programs can cause customers to consume more often goods or services offered by these companies.

Lee (2012) underscores that systematic efforts applied in order to achieve continuous improvement of quality increases business performance, providing the organization competitiveness needed to remain strong in the market.

\section{ANATEL}

ANATEL is one of 10 federally-created regulatory agencies supervise the provision of public services charged by the private sector, working in quality control and establishing rules for the sector. Established in 1997 the Agency has administrative and financial independence and is not subject to any government body. The ANATEL has the power of granting, regulation and supervision and must adopt measures necessary to take account of the interest of the citizen (ANATEL, 2011).

Its mission is to promote the development of telecommunications in the country, to give it a modern and efficient telecommunications infrastructure capable of providing adequate services to society, diverse and fairly priced throughout the national territory (ANATEL, 2011).

\section{Brazilian Mobile Phone Operators}

Brazilian mobile telephone operators recognized by ANATEL are allocated in two types "traditional operators" and "virtual operators". The basic difference is that traditional network suitable for operation and 
has the rent virtual network of a traditional operator to enable its operation. In total there are nine operators in these eight are traditional (Vivo, Claro, Tim, Oi, CTBC, Sercomtel, Aeiou, and Nextel) and only one is virtual (Porto Seguro), as described in Table 2.

Table 2

Characterization of Brazilian Mobile Telephone Operators

\begin{tabular}{|c|c|}
\hline (1) Operator: & Vivo S.A. \\
\hline Description: & $\begin{array}{l}\text { Formed by the merger of formerly State cellular companies in the country, was founded as a joint venture } \\
\text { between Portugal Telecom and Telefónica in Spain, and is commanded by the latter, after having bought the } \\
\text { position of first in July 2010. Its slogan is "Connected we live better". }\end{array}$ \\
\hline Coverage: & All of Brazil. \\
\hline (2) Operator: & Claro Serviços de Telecomunicações do Brasil S/A. \\
\hline Description: & $\begin{array}{l}\text { Result of the Union of six regional Operators: Americel, ATL, BCP Nordeste, BCP SP, Claro Digital e Tess. } \\
\text { In September } 2003 \text { was announced the consolidation of all these operators under a single brand, of course. It } \\
\text { is controlled by a Mexican company, Grupo América Móvil, one of the largest mobile telephony groups in } \\
\text { the world that, from 2006, went on to adopt the course in } 15 \text { countries in Latin America. Its slogan is "Share } \\
\text { every moment”. }\end{array}$ \\
\hline Coverage: & All of Brazil. \\
\hline (3) Operator: & TIM-Telecom Itália Mobile. \\
\hline Description: & $\begin{array}{l}\text { Cell phone company based in Italy, active also in Brazil. In Europe is part of the Free Move alliance. The } \\
\text { company is part of the Telecom Italia group, which also has operations in Argentina (Telecom Argentina), in } \\
\text { Bolivia (Entel), Cuba (ETECSA) in addition to its operations in Italy. Its slogan is "You, without borders". }\end{array}$ \\
\hline Coverage: & All of Brazil. \\
\hline (4) Operator: & Oi Móvel. \\
\hline Description: & $\begin{array}{l}\text { Started its operation as a cell-phone in } 2002 \text { as an arm of the Telemar Group was the first operator of Brazil } \\
\text { using GSM technology, the first ending with the fine for change of operator and second selling unlocked } \\
\text { handsets. Its slogan is "Simple like this". }\end{array}$ \\
\hline Coverage: & All of Brazil. \\
\hline (5) Operator: & CTBC_-Companhia de Telecomunicações do Brasil Central. \\
\hline Description: & $\begin{array}{l}\text { Offer services only to companies in Paraná, Rio de Janeiro, and Distrito Federal. CTBC was founded by } \\
\text { Alexandrino Garcia, who acquired the telephone company then Teixeirinha. It is one of the Algar group } \\
\text { companies. Its slogan is "CTBC. Proudly from here". }\end{array}$ \\
\hline Coverage: & Brazilian States: Goiás, Minas Gerais, Mato Grosso do Sul, and São Paulo. \\
\hline (6) Operator: & SERCOMTEL_-Serviço de Comunicações Telefônicas de Londrina. \\
\hline Description: & $\begin{array}{l}\text { Practice areas: fixed telephony, mobile telephony GSM, and } 3 \mathrm{~g} \text {, the latter by Sercomtel Celular. It is the } \\
\text { only public operator in the country. Its slogan is "1st quality service". }\end{array}$ \\
\hline Coverage: & Cities from North, Northeast, and South of Paraná State. \\
\hline (7) Operator: & UNICEL-aeiou. \\
\hline Description: & $\begin{array}{l}\text { Since May of } 2011 \text { the market disappeared: styrofoam leaving a debt of more than } 100 \text { million reais for the } \\
\text { auction held by ANATEL payments among the years of 2005-2007. Currently it is under legal lock for } \\
\text { performance in the market. }\end{array}$ \\
\hline Coverage: & Metropolitan area of São Paulo City. \\
\hline (8) Operator: & Nextel Telecomunicações S.A. \\
\hline Description: & $\begin{array}{l}\text { American company that started its operations in Brazil in 1997. His head is to serve corporate clients with } \\
\text { the "Radio Trunking”. The operation with telephone lines is still in an early stage. Its slogan is "Your world. } \\
\text { Now". }\end{array}$ \\
\hline Coverage: & Main cities of 11 Brazilian state more Distrito Federal State. \\
\hline (9) Operator: & Porto Seguro Telecom. \\
\hline Description: & $\begin{array}{l}\text { The first operator in Brazil to work with mobile virtual network, which in turn was granted by TIM. The } \\
\text { operator belongs to insurance Porto Seguro, aimed initially with this mobile network operation reduce } \\
\text { existing connections in more monitoring of } 500 \text { mil tracked vehicles via mobile telephone network. The } \\
\text { Telecom Datora is the responsible for the operation, traffic management, issuing bills, and interconnection } \\
\text { agreements. }\end{array}$ \\
\hline Coverage: & All of Brazil. \\
\hline
\end{tabular}




\section{Research Method}

As to the nature, this research is classified as applied. In relation to the objectives, this research is descriptive and exploratory. As for the approach this is classified as quantitative using the method "survey".

The development of the survey took place in two steps. The first matched the bibliographical research, in which it was necessary to review the existing literature and define the scope for the search, creating products such as the theoretical foundation and identification of the assumption of the research. The second was the documentary analysis phase, in which it was necessary to verify the common indicators of quality not existing in the database consulted, making possible the formation of the results.

The documentary analysis phase covered the data concerning the year of 2012, available in the Portal in the section “ANATEL Dados” and the Sindec Report published by the SENACON in the same year.

\section{Results}

The results described in this section have been divided into two subsections: "Brazilian Mobile Phone Market Dimensions: Active Lines, Involvement of Operators in the Market and Teledensity" and "Non-quality Indicators”.

Brazilian Mobile Phone Market Dimensions: Active Lines, Involvement of Operators in the Market and Teledensity

The year 2012 has finalized with 261,775,433 million active lines in Brazilian territory. 29.08\% of these lines are linked to Vivo operator, $24.92 \%$ to Claro, $26.87 \%$ to TIM, $18.81 \%$ to Oi Móvel, $0.28 \%$ to CTBC, $0.03 \%$ to Sercomtel, $0.0031 \%$ to Porto Seguro, and $0.000013 \%$ to Nextel. Unicel (aeiou) is blocked by government to sell mobile phone lines, so there are no active lines. The numbers presented in Table 3 qualifying the carrier Vivo as the largest operator in number of activated lines, followed by TIM in second, Claro in third, Oi Móvel in fourth, CTBC in fifth, Sercomtel in sixth, Porto Seguro in seventh, Nextel in eighth, and Unicel (aeiou) in ninth.

Table 3

Active Lines in 2012

\begin{tabular}{lllllllllll}
\hline & Vivo & Claro & Tim & Oi Móvel & CTBC & Serco. & Unic. & Porto & Nextel & Total \\
\hline Jan. & $72,885,253$ & $60,761,283$ & $65,126,458$ & $45,655,354$ & 673,411 & 77,281 & 0 & 0 & 0 & $245,179,040$ \\
Feb. & $73,916,795$ & $61,066,484$ & $65,916,842$ & $45,965,200$ & 675,627 & 77,100 & 0 & 0 & 0 & $247,618,048$ \\
Mar. & $74,783,713$ & $61,595,980$ & $67,217,384$ & $46,469,208$ & 683,604 & 76,482 & 0 & 0 & 0 & $250,826,371$ \\
Apr. & $75,264,525$ & $61,938,763$ & $68,024,647$ & $46,976,184$ & 701,821 & 76,204 & 0 & 0 & 0 & $252,982,144$ \\
May & $75,538,746$ & $62,688,017$ & $68,536,385$ & $47,402,971$ & 705,940 & 76,875 & 0 & 0 & 0 & $254,948,934$ \\
June & $75,719,728$ & $62,966,248$ & $68,873,683$ & $47,771,900$ & 725,438 & 74,070 & 0 & 0 & 0 & $256,131,067$ \\
July & $76,181,210$ & $45,038,477$ & $68,672,340$ & $47,661,864$ & 744,798 & 73,496 & 0 & 2,000 & 0 & $238,374,185$ \\
Aug. & $76,487,040$ & $45,235,624$ & $69,395,736$ & $47,969,389$ & 747,328 & 72,488 & 0 & 8,000 & 0 & $239,915,605$ \\
Sep. & $76,805,554$ & $45,368,493$ & $69,408,234$ & $48,375,988$ & 743,917 & 72,099 & 0 & 8,300 & 0 & $240,782,585$ \\
Oct. & $76,279,692$ & $45,587,534$ & $69,460,373$ & $48,833,698$ & 733,089 & 71,186 & 0 & 8,300 & 0 & $240,973,872$ \\
Nov. & $75,979,811$ & $64,353,443$ & $69,534,884$ & $49,362,112$ & 736,831 & 68,051 & 0 & 8,300 & 0 & $260,043,432$ \\
Dec. & $76,137,268$ & $65,238,342$ & $70,343,480$ & $49,237,532$ & 740,968 & 69,507 & 0 & 8,300 & 36 & $261,775,433$ \\
\hline
\end{tabular}

Vivo operator started 2012 as champion in activation of lines, with 1,331,653 enabled lines in January and 1,031,542 million in February, registering January to September a gradual growth in the amount of activated 
lines between $0.24 \%$ and $1.86 \%$. In the months of October and November, the carrier noted a reduction in lines of $-0.68 \%$ as compared to September, and $-0.39 \%$ compared to October. He finished with a 2012 resume growth of $0.21 \%$ in December. Vivo was the carrier with more activated lines in the months of January, February, and July.

The Claro operator registered from January to June a gradual growth in the amount of activated lines between $0.44 \%$ and $1.21 \%$. In July recorded the biggest loss of lines throughout the year, between all operators, with remarkable reduction of $-28.7 \%$ corresponding to $17,927,711$ million lines. In the last five months of the year to clear recorded a recovery also noted, accounting for successive booms of $0.44 \%, 0.29 \%, 0.48 \%$, and 41.6\%, surpassing the incredible loss of July with an increase of 18,765,909 million lines in your network. Finalized 2012 with growth of $1.38 \%$ in December. Claro was the carrier with more activated lines in the months of May, November, and December.

The operator TIM grew gradually in the amount of active lines between $0.02 \%$ and $1.97 \%$ for almost all year, just in the month of July showed a decrease of $-0.29 \%$, which corresponds to removing -201.343 thousand lines in your network. In March the carrier enabled 1,300,542 million lines, his best result in the whole year. Finalized 2012 with growth of $1.16 \%$ in December. TIM was the carrier more activated lines in the months of March, April, and August.

The operator Oi Móvel recorded a gradual growth by June in the number of active lines between $0.68 \%$ and $1.10 \%$. His first low in number of rows was noted in July, with a reduction of -110.036 thousand lines, corresponding to $-0.23 \%$ over the month of June. Resumed gradual growth covering August until November between $0.65 \%$ and $1.08 \%$. He finished 2012 with reduction -124.580 lines in its network, corresponding to $-0.25 \%$ in relation to November. The mobile operator that more Oi Móvel activated lines in the months of June, September, and October.

The operator CTBC recorded gradual growth until August in the number of active lines between $+0.33 \%$ and $+2.98 \%$. His first low in number of rows was noted in September, with a reduction of -3.411 thousand lines, corresponding to $-0.46 \%$ over the month of August. Again in October noted a reduction of lines, with lows of $-10,828$ thousand lines in the network, corresponding to $-1.46 \%$ over the month of September. Resumed the growth in the number of lines in November, with percentage growth of $0.51 \%$ compared to October. Finalized 2012 with growth of $0.56 \%$ in December.

The Sercomtel recorded low in their workforce in the months of February, March, April, June, July, August, September, October, and November, with percentages of reduction ranging from $-0.23 \%$ to $-4.40 \%$. Only in the months of January, May, and December the carrier recorded increases in their activations, with percentage growth ranging from $+0.02 \%$ to $+2.14 \%$. Finalized 2012 with growth of $+2.14 \%$ in December .

The operator Porto Seguro began operations in July with activation of 2,000 thousand lines. In August turned over 4,000 thousand lines, totaling 6,000 thousand. In September recorded the most activation 375 lines, since then have not noticed growth in your network.

Nextel started his carrier activation of mobile phone lines in December, with only 36 active lines. The highlight of Nextel in Brazil, is in radio communication.

In general, the mobile phone market presented January until June a gradual growth between $+0.46 \%$ and $+1.30 \%$ in the activation of mobile lines. The only significant low in July, where it was registered a $-6.93 \%$ reduction in active lines, corresponding to the exclusion of 17,756,882 million lines in use. The gradual growth resumed as of August, aiming to increase percentages between $+0.65 \%$ and $+7.91 \%$, highlighting the month of 
November, with the addition of 19,069,560 million active lines. The year 2012 has finalized with percentage growth of $+0.67 \%$, in number of rows qualified for November. The numbers presented in Table 4 , justify the results.

Table 4

Monthly Increase of Telephone Lines in 2012

\begin{tabular}{clllllllll}
\hline & Vivo & Claro & Tim & Oi Móvel & CTBC & S.Tel & Porto & Next & Total \\
\hline Jan. & $1,331,653$ & 381,781 & $1,043,309$ & 171,272 & 19,506 & 16 & 0 & 0 & $2,947,537$ \\
& $(+1.86 \%)$ & $(+0.63)$ & $(+1.63 \%)$ & $(+0.38 \%)$ & $(+2.98 \%)$ & $(+0.02 \%)$ & 0 & & $(+1.22 \%)$ \\
Feb. & $1,031,542$ & 305,201 & 790,384 & 309,846 & 2,216 & -181 & 0 & 0 & $2,439,008$ \\
& $(+1.42 \%)$ & $(+0.50)$ & $(+1.21 \%)$ & $(+0.68 \%)$ & $(+0.33 \%)$ & $(-0.23 \%)$ & & & $(+0.99 \%)$ \\
Mar. & 866,918 & 529,496 & $1,300,542$ & 504,008 & 7,977 & -618 & 0 & 0 & $3,208,323$ \\
& $(+1.17 \%)$ & $(+0.87 \%)$ & $(+1.97 \%)$ & $(+1.10 \%)$ & $(+1.18 \%)$ & $(-0.80 \%)$ & & & $(+1.30 \%)$ \\
Apr. & 480,812 & 342,783 & 807,263 & 506,976 & 18,217 & -278 & 0 & 0 & $2,155,773$ \\
& $(+0.64 \%)$ & $(+0.56 \%)$ & $(+1.20 \%)$ & $(+1.09 \%)$ & $(+2.66 \%)$ & $(-0.36 \%)$ & & $(+0.86 \%)$ \\
May & 274,221 & 749,254 & 511,738 & 426,787 & 4,119 & 671 & 0 & 0 & $1,966,790$ \\
& $(+0.36 \%)$ & $(+1.21 \%)$ & $(+0.75 \%)$ & $(+0.91 \%)$ & $(+0.59 \%)$ & $(+0.88 \%)$ & & & $(+0.78 \%)$ \\
June & 180,982 & 278,231 & 337,298 & 368,929 & 19,498 & $-2,805$ & 0 & 0 & $1,182,133$ \\
& $(+0.24 \%)$ & $(+0.44 \%)$ & $(+0.49 \%)$ & $(+0.78 \%)$ & $(+2.76 \%)$ & $(-3.65 \%)$ & & & $(+0.46 \%)$ \\
July & 461,482 & $-17,927,771$ & $-201,343$ & $-110,036$ & 19,360 & -574 & 2.000 & 0 & $-17,756,882$ \\
& $(+0.61 \%)$ & $(-28.47 \%)$ & $(-0.29 \%)$ & $(-0.23 \%)$ & $(+2.67 \%)$ & $(-0.77 \%)$ & & $(-6.93 \%)$ \\
Aug. & 305,830 & 197,147 & 723,396 & 307,525 & 2,530 & $-1,008$ & 6.000 & & $1,541,420$ \\
& $(+0.40 \%)$ & $(+0.44 \%)$ & $(+1.05 \%)$ & $(+0.65 \%)$ & $(+0.34 \%)$ & $(-1.37 \%)$ & $(+300 \%)$ & 0 & $(+0.65 \%)$ \\
Sep. & 318,514 & 132,869 & 12,498 & 406,599 & $-3,411$ & -389 & 300 & 0 & 866,980 \\
& $(+0.42 \%)$ & $(+0.29 \%)$ & $(+0.02 \%)$ & $(+0.85 \%)$ & $(-0.46 \%)$ & $(-0.54 \%)$ & $(+3.75 \%)$ & 0 & $(+0.36 \%)$ \\
Oct. & $-525,862$ & 219,041 & 52,139 & 457,710 & $-10,828$ & -913 & 0 & & 191,287 \\
& $(-0.68 \%)$ & $(+0.48 \%)$ & $(+0.08 \%)$ & $(+0.95 \%)$ & $(-1.46 \%)$ & $(-1.27 \%)$ & $(0.00 \%)$ & 0 & $(+0.08 \%)$ \\
Nov. & $-299,881$ & $18,765,909$ & 74,511 & 528,414 & 3,742 & $-3,135$ & 0 & & $19,069,560$ \\
& $(-0.39 \%)$ & $(+41.6 \%)$ & $(+0.11 \%)$ & $(+1.08 \%)$ & $(+0.51 \%)$ & $(-4.40 \%)$ & $(0.00 \%)$ & 0 & $(+7.91 \%)$ \\
Dec. & 157,457 & 884,899 & 808,596 & $-124,580$ & 4,137 & 1,456 & 0 & \\
\hline
\end{tabular}

As shown in Table 5, in total in 2012 the mobile phone market absorbed 19,543,930 million new lines, corresponding to a growth of $8.07 \%$ from 2011 , these lines $80.53 \%$ are prepaid and $19.47 \%$ postpaid. CTBC was the carrier that has grew more in the year, with an increase of $13.31 \%$ in their lines. Sercomtel was the only company showed reduction in their active lines in $-10.04 \%$. Among the four largest carriers (Vivo, Claro, TIM, and Oi Móvel) who else grew up was TIM, with 9.77\% increase in their lines. Already the Live recorded lower growth rate, noting an increase of $6.41 \%$ in the year. TIM was the carrier that activated the greater number of lines in 2012, with 6,260,331 enabling millions of rows.

Table 5

Annual Increase of Telephone Lines in 2012

\begin{tabular}{lllllllll}
\hline Vivo & Claro & Tim & Oi Móvel & CTBC & Sercomtel & Porto Seguro & Nextel & Total \\
\hline $\mathbf{4 , 5 8 3 , 6 6 8}$ & $4,858,840$ & $6,260,331$ & $3,753,450$ & 87,063 & $-\begin{array}{l}-7,758 \\
(-10.04 \%)\end{array}$ & 8,300 & 36 & $\begin{array}{l}19,543.930 \\
(+8.07 \%)\end{array}$ \\
\hline$(+6.41 \%)$ & $(+8.05 \%)$ & $(+9.77 \%)$ & $(+8.25 \%)$ & $(+13.31 \%)$ & & 36 \\
\hline
\end{tabular}

As shown in Table 6, the Vivo operator started the year of 2012 having mobile phone market share of $29.73 \%$, remaining at the home of $29 \%$ throughout the year, giving it the lead in the market. TIM is in second place with a $26.87 \%$ stake, keeping the level of $26 \%$ during almost every year, except in September, which recorded a drop to $17.53 \%$, soon recovered to level $26 \%$ in October and held in November and December. The Claro is in the third place with a $24.92 \%$ stake, keeping the level of $24 \%$ during the year, registering 0.75 falls from July to October to the level of $17 \%$, recovered to the level of $24 \%$ in November and held in December. Oi 
Móvel lies in the fourth place with $18.81 \%$, remaining at the level of $18 \%$ all the year. CTBC is in the fifth place with $0.28 \%$, remaining at between $0.27 \%$ and $0.29 \%$ all year. Sercomtel is in the sixth place with $0.03 \%$ and remained stable throughout the year. The Porto Seguro, Nextel, and Unicel (aeiou) have participation respectively, almost null, null, and void in the market, because the few active lines under its operation in the market.

Table 6

Percentage of Participation of Operators in Mobile Telephone Brazilian Market

\begin{tabular}{lcclllllll}
\hline & Vivo & Claro & Tim & $\begin{array}{l}\text { Oi } \\
\text { Móvel }\end{array}$ & CTBC & Sercomtel & Unicel & Porto Seguro & Nextel \\
\hline Jan. & 29.73 & 24.78 & 26.56 & 18.62 & 0.27 & 0.03 & 0 & 0 & 0 \\
Feb. & 29.85 & 24.66 & 26.62 & 18.56 & 0.27 & 0.03 & 0 & 0 & 0 \\
Mar. & 29.81 & 24.56 & 26.80 & 18.53 & 0.27 & 0.03 & 0 & 0 & 0 \\
Apr. & 29.75 & 24.48 & 26.89 & 18.57 & 0.28 & 0.03 & 0 & 0 & 0 \\
May & 29.63 & 24.59 & 26.88 & 18.59 & 0.28 & 0.03 & 0 & 0 & 0 \\
June & 29.56 & 24.58 & 26.89 & 18.65 & 0.28 & 0.03 & 0 & 0 & 0 \\
July & 29.71 & 17.56 & 26.78 & 18.59 & 0.29 & 0.03 & 0 & 0 & 0 \\
Aug. & 29.66 & 17.54 & 26.91 & 18.60 & 0.29 & 0.03 & 0 & 0 & 0 \\
Sep. & 29.67 & 17.53 & 17.53 & 18.69 & 0.29 & 0.03 & 0 & 0 & 0 \\
Oct. & 29.42 & 17.58 & 26.79 & 18.83 & 0.28 & 0.03 & 0 & 0 & 0 \\
Nov. & 29.22 & 24.75 & 26.74 & 18.98 & 0.28 & 0.03 & 0 & 0 & 0 \\
Dec. & 29.08 & 24.92 & 26.87 & 18.81 & 0.28 & 0.03 & 0 & 0 & 0 \\
\hline
\end{tabular}

In Brazil the registered in 2012 had a teledensity (see Table 7), is of 132.78 rows each 100 inhabitants. Among the regions, the Midwest registers biggest had a teledensity, 158.55 lines.

Table 7

Teledensity in 2012

\begin{tabular}{lrl}
\hline Region & Active lines & Teledensity (per 100 habitants) \\
\hline Midwest & $23,090,648$ & 158.55 \\
North-east & $64,477,685$ & 116.07 \\
North & $19,606,997$ & 120.91 \\
South-east & $116,358,565$ & 141.2 \\
South & $38,241,538$ & 134.58 \\
Brazil & $261,775,433$ & 132.78 \\
\hline
\end{tabular}

\section{Non-quality Indicators}

Among the 15 kinds of non-quality in the provision of service by the Brazilian mobile telephony operators presented (see Table 8), were recorded by the users complaint ANATEL in 2012 between January and October (period computed by the agency), the misappropriation was the most cited, above the triple registered in each of the 15 reasons. Then non-quality indicators with higher frequency of complaints were "other reasons" on second, "additional services" in third, "service plans" in fourth, "service repair" in fifth, "repair" in sixth, "attendance" in seventh, "cancellation service" in eighth, "Deals" in ninth, and "blocking services" in tenth, completing the Top 10 complaints registered by ANATEL, as shown in Table 9. 
Table 8

Origins of Non-quality

\begin{tabular}{|l|l|}
\hline Origin & Description \\
\hline Charges & Undue collection of contracted services. \\
\hline Additional services & No additional services run as: internet access, SMS sending, etc. \\
\hline Service plans & Not full availability of contracted services. \\
\hline Attendance & Difficulty contact customer service telephone exchange. \\
\hline Canceling & Difficulty in effecting the cancellation of contracted services. \\
\hline Repair & Difficulty in effecting the repair/replacement of mobile phones and modems. \\
\hline Habilitation & Problems on activation/operation of the contracted services. \\
\hline Promotions & Full availability benefits not promoted by promotions. \\
\hline Blocking & Blocking of services contracted by virtue of non-recognition. \\
\hline Unblocking & Unlock the contracted services because of delay/non-recognition of payment. \\
\hline Pre-paid card & Problems for prepaid reloading via card system. \\
\hline Complete callings & Break (fall line) constant during phone calls. \\
\hline Access code & Problems in qualification of the chips via access code PIN and PUK. \\
\hline Coverage area & Problems in the area of coverage of operators leaving the mobile devices outside of the network. \\
\hline Other reasons & Other issues that do not fit the 14 previously described natures. \\
\hline
\end{tabular}

Table 9

Number of Complaints Due the Offender During 2012

\begin{tabular}{lrrrrrrrrrr}
\hline & Jan. & \multicolumn{1}{c}{ Feb. } & \multicolumn{1}{c}{ Mar. } & \multicolumn{1}{l}{ Apr. } & \multicolumn{1}{l}{ May } & \multicolumn{1}{l}{ June } & \multicolumn{1}{l}{ July } & \multicolumn{1}{l}{ Aug. } & \multicolumn{1}{l}{ Sep. } & Oct. \\
\hline Charging & 38,758 & 33,710 & 38,246 & 33,456 & 37,976 & 31,510 & 38,210 & 43,847 & 37,624 & 44,962 \\
Additional services & 8,612 & 6,591 & 7,989 & 6,982 & 7,761 & 7,047 & 9,932 & 12,999 & 11,524 & 11,626 \\
Service plans & 6,684 & 5,060 & 5,837 & 4,988 & 5,905 & 4,684 & 4,925 & 6,193 & 5,180 & 5,984 \\
Attendance & 6,047 & 4,999 & 5,650 & 4,679 & 5,048 & 3,890 & 4,345 & 5,758 & 5,308 & 6,200 \\
Canceling & 5,197 & 4,361 & 5,322 & 4,751 & 5,516 & 4,189 & 4,656 & 5,297 & 5,203 & 5,887 \\
Repair & 4,252 & 3,648 & 3,989 & 3,833 & 5,351 & 3,933 & 5,018 & 7,700 & 7,210 & 7,073 \\
Habilitation & 4,258 & 3,465 & 4,327 & 3,793 & 4,758 & 4,063 & 4,778 & 5,269 & 4,299 & 4,879 \\
Promotions (Deals) & 3,766 & 3,280 & 3,432 & 3,510 & 4,432 & 3,542 & 3,520 & 5,270 & 3,403 & 3,524 \\
Blocking & 3,191 & 3,104 & 3,336 & 3,102 & 3,603 & 3,307 & 3,706 & 4,303 & 3,560 & 4,626 \\
Unblocking & 2,530 & 1,957 & - & - & - & - & - & - & - & - \\
Pre-paid card & - & - & 2,212 & - & - & - & - & 3,510 & 3,173 & 3,558 \\
Complete callings & - & - & - & - & 2,432 & - & - & - & - & - \\
Access code & - & - & - & 1,980 & - & 2,087 & - & - & - & - \\
Coverage area & - & - & - & - & - & 2,916 & - & - & - & - \\
Other reasons & 9,025 & 8,098 & 9,308 & 8,315 & 11,161 & 9,514 & 11,284 & 14,066 & 11,498 & 13,727 \\
Total & 92,320 & 78,633 & 89,648 & 79,389 & 93,943 & 77,766 & 93,290 & 114,212 & 97,982 & 112,046 \\
\hline
\end{tabular}

The index presented in Table 10 is the result of the division between the numbers of complaints by the number of active lines, multiplied by 1,000. Oi Móvel, in all months registered by ANATEL in 2012 (Jan.-Oct.), pointed out have highest rates of complaints.

Already the Ranking is shown in Table 11, the four major carriers stand out negatively, being among the 10 conglomerates with the largest number of complaints registered, and again the Oi Móvel appeared the first place. 
Table 10

Ranking of Complaints in the ANATEL Call Center Until October/2012

\begin{tabular}{|c|c|c|c|c|c|c|c|c|c|c|}
\hline Position & Jan. & Feb. & Mar. & Apr. & May & June & July & Aug. & Sep. & Oct. \\
\hline \multirow{2}{*}{$1 \mathrm{st}$} & 0.534 & 0.476 & 0.474in & 0.413 & 0.595 & 0.503 & 0.549 & 0.641 & 0.565 & 0.627 \\
\hline & (Oi) & (Oi) & (Oi) & (Oi) & (Oi) & (Oi) & (Oi) & (Oi) & $(\mathrm{Oi})$ & (Oi) \\
\hline 2nd & $\begin{array}{l}0.469 \\
\text { (Claro) }\end{array}$ & $\begin{array}{l}0.403 \\
\text { (Claro) }\end{array}$ & $\begin{array}{l}0.467 \\
\text { (Claro) }\end{array}$ & $\begin{array}{l}0.380 \\
\text { (Claro) }\end{array}$ & $\begin{array}{l}0.424 \\
\text { (Claro) }\end{array}$ & $\begin{array}{l}0.344 \\
\text { (Claro) }\end{array}$ & 0.438 & $\begin{array}{l}0.499 \\
\text { (Claro) }\end{array}$ & 0.413 & 0.467 \\
\hline \multirow{2}{*}{ 3rd } & 0.310 & 0.260 & 0.294 & 0.266 & 0.298 & 0.240 & 0.320 & 0.440 & 0.348 & 0.413 \\
\hline & (Tim) & (Tim) & (Tim) & (Tim) & (Tim) & (Tim) & (Tim) & (Tim) & (Tim) & (Tim) \\
\hline 4th & $\begin{array}{l}0.238 \\
\text { (Vivo) }\end{array}$ & $\begin{array}{l}0.200 \\
\text { (Vivo) }\end{array}$ & $\begin{array}{l}0.252 \\
\text { (Vivo) }\end{array}$ & $\begin{array}{l}0.242 \\
\text { (Vivo) }\end{array}$ & $\begin{array}{l}0.246 \\
\text { (Vivo) }\end{array}$ & $\begin{array}{l}0.202 \\
\text { (Vivo) }\end{array}$ & $\begin{array}{l}0.227 \\
\text { (Vivo) }\end{array}$ & $\begin{array}{l}0.277 \\
\text { (Vivo) }\end{array}$ & $\begin{array}{l}0.258 \\
\text { (Vivo) }\end{array}$ & $\begin{array}{l}0.297 \\
\text { (Vivo) }\end{array}$ \\
\hline 5th & $\begin{array}{l}0.190 \\
\text { (CTBC) }\end{array}$ & $\begin{array}{l}0.161 \\
\text { (CTBC) }\end{array}$ & $\begin{array}{l}0.187 \\
\text { (CTBC) }\end{array}$ & $\begin{array}{l}0.144 \\
\text { (CTBC) }\end{array}$ & $\begin{array}{l}0.188 \\
\text { (CTBC) }\end{array}$ & $\begin{array}{l}0.175 \\
\text { (CTBC) }\end{array}$ & $\begin{array}{l}0.197 \\
\text { (CTBC) }\end{array}$ & $\begin{array}{l}0.186 \\
\text { (CTBC) }\end{array}$ & $\begin{array}{l}0.198 \\
\text { (СTBC) }\end{array}$ & $\begin{array}{l}0.226 \\
\text { (CTBC) }\end{array}$ \\
\hline 6th & $\begin{array}{l}0.052 \\
\text { (S.tel) }\end{array}$ & $\begin{array}{l}0.013 \\
\text { (S.tel) }\end{array}$ & $\begin{array}{l}0.026 \\
\text { (S.tel) }\end{array}$ & $\begin{array}{l}0.039 \\
\text { (S.tel) }\end{array}$ & $\begin{array}{l}0.039 \\
\text { (S.tel) }\end{array}$ & $\begin{array}{l}0.041 \\
\text { (S.tel) }\end{array}$ & $\begin{array}{l}0.054 \\
\text { (S.tel) }\end{array}$ & $\begin{array}{l}0.014 \\
\text { (S.tel) }\end{array}$ & $\begin{array}{l}0.014 \\
\text { (S.tel) }\end{array}$ & $\begin{array}{l}0.042 \\
\text { (S.tel) }\end{array}$ \\
\hline
\end{tabular}

Table 11

Economic Conglomerates More Defendants in SENACON in 2012

\begin{tabular}{llcl}
\hline Position & Conglomerate & No. of complaints & Sector \\
\hline $1^{\circ}$ & Oi Móvel & 120,374 & Telephoning \\
$2^{\text {o }}$ & Claro/Embratel & 102,682 & Telephoning \\
$3^{\text {o }}$ & Itaú & 97,578 & Banking \\
$4^{\text {o }}$ & Bradesco & 61,257 & Banking \\
$5^{\text {o }}$ & Vivo/Telefônica & 44,022 & Telephoning \\
$6^{\text {o }}$ & Sky & 33,520 & Cable TV \\
$7^{\text {o }}$ & Tim/Interlig & 32,286 & Telephoning \\
$8^{\text {o }}$ & Santander & 31,936 & Banking \\
$9^{\circ}$ & Ponto Frio/Casas Bahia & 28,531 & Retail Sales \\
$10^{\circ}$ & Ricardo Eletro/Insinuante/City Lar/Eletro Shopping & 26,808 & Retail Sales \\
\hline
\end{tabular}

\section{Conclusions}

The increase of 19 million lines in 2012 at the level presented in ally had a teledensity in the country of 132 hits every 100 habitants confirms the growing expansion of the mobile phone market. The popularity of cell phones, sold at affordable prices and the ease in enabling a phoneline, made zero cost these days, makes the Brazilian consumer activate your lines often, already considering a disposable product.

The gap between the Oi Móvel (the 4th largest) and CTBC (5th largest) in amount of active lines, assumes the continuation of the mobile phone market monopolization by the four major (Vivo, Claro, TIM, and Oi Móvel) of the Vivo with a higher market share, followed closely by TIM and Claro and Oi Móvel a less stage.

Vivo, the market leader, has demonstrated the best results as the provision of its services and is in fourth place in the ranking of claims. TIM, the second carrier with the largest number of active lines, is coming soon in front of occupying the 3rd placing. Of course, the third-largest carrier, comes in second place in the rankings and in 1st place is Oi Móvel, the fourth largest in the market. It is interesting highlight the inverse relationship between market share and complaints ranking position, noting that the higher the market share, the lower the number of complaints registered.

However, even if on a smaller scale, it has been pointed out problems in the services provided by all carriers. In general, numbers of 15 kinds of flaws pointed out by users in the use of contracted services, predominantly prevails improper billing, leading often to a halt, since operators effect the inclusion of 
Customer Credit Protection Service-SPC (resulting in the impediment in granting credit on the part of companies all over the Brazil), and before the fact, if feeling charged improperly and without effective debt correction response by carriers, clients activate lawsuits requiring in most cases punitive damages.

The term "sustainable growth" is well away from the understanding on the part of the operators. The growth of contrast enabled lines of stagnation in the evolution of operational infrastructure was detected by ANATEL. In retaliation, the Agency acted rigidly by enabling blocking new lines, which impacted not only increasing but also in the reduction of active lines. To return to normalcy has been operators required formatting an infrastructural expansion plan, providing for improvements in the sector, which so far is not being perceived by users.

The dissatisfaction on the part of Brazilian society with regard to the services provided by mobile phone operators is fait accompli. It is very common that users report informally their negative experiences in the use of contracted services. This framework recognized by competent organs ANATEL and SENACON, coming to encourage the formalization of those complaints, for that have support their actions in trying to promote the improvement of services provided by carriers.

\section{References}

Agência Nacional de Telecomunicações (ANATEL). (2011). Annual report-2011 (Relatório Anual-2011). Retrieved December 23, 2012, from http://www.anatel.gov.br

Agência Nacional de Telecomunicações (ANATEL). (2012). ANATEL data (ANATEL Dados). Retrieved December 20, 2012, from http://www.anatel.gov.br

Associação Brasileira de Normas Técnicas (ABNT). (2008). ISO 9001 : 2008—Quality management systems—Requirements (ISO 9001:2008—Sistemas de Gestão da Qualidade—Requisitos). Rio de janeiro: ABNT.

Churchill, G. A., \& Peter, J. P. (2003). Marketing: Creating value for customers (Marketing: criando valor para os clients). São Paulo: Saraiva.

Crosby, P. B. (1990). Quality is investment (Qualidade é investimento). Rio de Janeiro: José Olympio.

Deming, W. E. (1993). Dr. Deming: The American who taught the Japanese total quality (Dr. Deming: o Americano que ensinou qualidade total aos japoneses). Rio de Janeiro: Record.

Diogenes, J. R. F., Sousa, C. K., Queiroz, F. C. B. P., Queiroz, J. V., \& Hékis, H. R. (2013). Adopting quality practices by automotive dealerships located in Natal/RN, Brazil. Revista Latino-Americana de Inovação e Engenharia de Produção, 1, 59-72.

Feigenbaum, A. V. (1994). Total quality control (Controle da Qualidade Total). São Paulo: Makron Books.

Fuentes-Fuentes, M. M., Llorens-Montes, F. J., Molina-Fernandes, L. M., \& Albacete-Saez, C. A. (2011). Environment-quality management co alignment across industrial contexts: An empirical investigation of performance implications. Industrial Marketing Management, 40, 730-742.

International Telecommunication Union (ITU). (2012). Free statistics: Mobile-cellular telephony. Retrieved December 20, 2012, from http://www.itu.int/ITU-D/ict/statistics/

Ishikawa, K. (1993). Total quality control: The Japanese way (Controle da Qualidade Total: A maneira Japonesa). Rio de Janeiro: Campos.

Juran, J. M. (1990). Juran on leadership for quality (Juran na Liderança pela Qualidade). São Paulo: Pioneira.

Kaynak, K. (2003). The relationship between total quality management practices and their effects of firm performance. Journal of Operations Management, 21(4), 405-435.

Lagrosen, S., \& Lagrosen, Y. (2003). Quality configurations: A contingency approach to quality management. International Journal of Quality and Reliability Management, 20(7), 759-773.

Lee, D. H. (2012). Implementation of quality programs in health care organizations. Service Business, 6(3), 387-404.

Levitt, T. (1990). The marketing imagination (A imaginação de marketing). São Paulo: Editora Atlas.

Powell, T. (1995). Total quality management as competitive advantage: A review and empirical study. Strategic Management Journal, 16(1), 15-37. 
Rahman, S. U. (2004). The future of TQM is past, can TQM be resurrected? Total Quality Management and Business Excellence, 15(4), 411-422.

Secretária Nacional do Consumidor (SENACON). (2012). Sindec Report 2012 (Boletim Sindec 2012). Retrieved December 23, 2012, from http://portal.mj.gov.br

Srivastav, A. K. (2010). Impact of ISO 9000 implementation on the organization. International Journal of Quality and Reliability Management, 27(4), 438-450.

TELECO. (2012). The impact of the punishment of ANATEL in cellular growth in Brazil (O impacto da punição da ANATEL no crescimento do celular no Brasil). Retrieved December 20, 2012, from http://www.teleco.com.br/comentario/com481.asp

UOL. (2013). ANATEL “fight" for U.S. \$ 194 million in fines have not been paid (ANATEL "briga” por R\$ 194 milhões em multas que não foram pagas). Retrieved December 20, 2012, from http://olhardigital.uol.com.br/negocios/digital_news/noticias/anatel-briga-por-r-194-milhoes-em-multas-que-nao-foram-pagas 